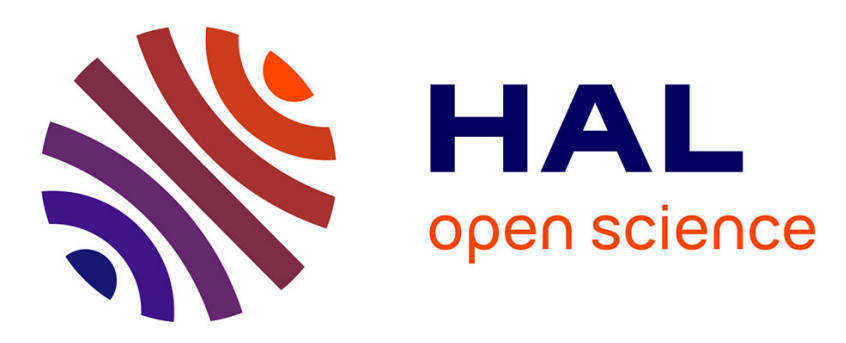

\title{
A luminescence-based chronology for the Harletz loess sequence, Bulgaria
}

Johanna Lomax, Markus Fuchs, Pierre Antoine, Denis-Didier Rousseau, France Lagroix, Christine Hatté, Samuel Taylor, Jessica Till, Maxime Debret, Olivier Moine, et al.

\section{To cite this version:}

Johanna Lomax, Markus Fuchs, Pierre Antoine, Denis-Didier Rousseau, France Lagroix, et al.. A luminescence-based chronology for the Harletz loess sequence, Bulgaria. Boreas, 2019, 48 (1), pp.179194. 10.1111/bor.12348 . hal-02352640

\section{HAL Id: hal-02352640 https://hal.science/hal-02352640}

Submitted on 1 Apr 2021

HAL is a multi-disciplinary open access archive for the deposit and dissemination of scientific research documents, whether they are published or not. The documents may come from teaching and research institutions in France or abroad, or from public or private research centers.
L'archive ouverte pluridisciplinaire HAL, est destinée au dépôt et à la diffusion de documents scientifiques de niveau recherche, publiés ou non, émanant des établissements d'enseignement et de recherche français ou étrangers, des laboratoires publics ou privés. 


\section{open $\partial$ access}

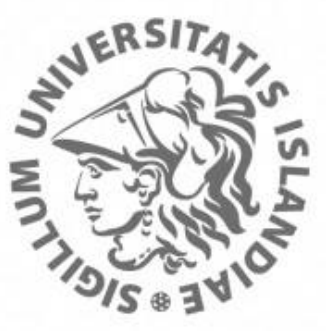

Bopin vísindl

This is not the published version of the article / Petta er ekki útgefna útgáfa greinarinnar

Author(s)/Höf.: Johanna Lomax, Markus Fuchs, Pierre Antoine, Denis-didier Rousseau, France Lagroix, Christine Hatté, Samuel Neil Taylor, Jessica Lynn Till, Olivier Moine And Diana Jordanova

Title/Titill:

A luminescence based chronology for the Harletz loess sequence, Bulgaria

Year/Útgáfuár: $\quad 2018$

Version/Útgáfa: $\quad$ Pre-print (Óritrýnt handrit)

Please cite the original version:

Vinsamlega vísið til útgefnu greinarinnar:

Lomax, J., Fuchs, M., Antoine, P., Rousseau, D.-D., Lagroix, F., Hatté, C., ... Jordanova, D. (2019). A luminescence-based chronology for the Harletz loess sequence, Bulgaria. Boreas, 48(1), 179-194. doi:10.1111/bor.12348

Rights/Réttur: $\quad$ Copyright (c) 1999-2019 John Wiley \& Sons, Inc. All rights reserved 
Johanna Lomax (johanna.lomax@geogr.uni-giessen.de) and Markus Fuchs, Department of Geography, Justus-Liebig-University Giessen, 35390 Giessen, Germany; Pierre Antoine and Olivier Moine, UMR CNRS-Univ. Paris 1-UPEC 8591, Laboratoire de Géographie Physique, 92195 Meudon, France; Denis-Didier Rousseau, Ecole Normale Supérieure de Paris, Laboratoire de Météorologie Dynamique, UMR CNRS 8539, 75231 Paris, France and Lamont-Doherty Earth Observatory of Columbia University, Palisades, NY 10964, USA; France Lagroix, Samuel Neil Taylor and Jessica Lynn Till, Institut de Physique du Globe de Paris, Sorbonne Paris Cité, Univ Paris Diderot, UMR 7154 CNRS, 75005 Paris, France; Christine Hatté, Laboratoire des Sciences du Climat et de l'Environnement, UMR 8212 CEA-CNRS-UVSQ, Université Paris-Saclay, 91198 Gif-sur-Yvette, France; Jessica Lynn Till, Institute of Earth Sciences, University of Iceland, 101 Reykjavik, Iceland; Maxime Debret, UFR Sciences et Techniques, Université de Rouen Normandie, 76000 Rouen, France; Diana Jordanova, National Institute of Geophysics, Geodesy and Geography, Bulgarian Academy of Sciences, Sofia, Bulgaria; received 8th January 2018, accepted 21 th August 2018. 
1 Loess-paleosol-sequences are important pedo-sedimentary archives, allowing to reconstruct

2 palaeoenvironmental parameters such as variations in both wind directions and speeds, aridity,

3 sediment supply, and vegetation cover but also temperature and precipitation. This information is only

4 useful, when a detailed chronology is provided along with the palaeoenvironmental information

5 released from the available proxies. In order to establish a numerical chronology in loess deposits,

6 basically two methods are available. One is radiocarbon dating, which has been successfully applied

7 for example to mollusc shells at Dunaszeckcső (Hungary) (Újvári et al. 2014) and to earthworm

8 calcite granules at Nussloch (Germany) (Moine et al. 2017). But since radiocarbon dating has an upper

9 age limit of around $45 \mathrm{ka}$ and can thus only date Last Glacial loess, the standard method for dating loess, especially for a timeframe beyond $45 \mathrm{ka}$, are luminescence techniques.

In many sedimentary contexts, optically stimulated luminescence (OSL) dating of quartz is preferred over infrared stimulated luminescence (IRSL) dating of the feldspar fraction, because the quartz signal is assumed to be athermally stable, as opposed to feldspar, which shows anomalous fading of the signal, which can lead to significant age underestimation. Loess deposits though usually have high dose rates of around $3 \mathrm{~Gy} \mathrm{ka}^{-1}$, which makes quartz problematic with respect to the upper age limit. A range of studies show that above a stored paleodose of around 150-200 Gy the quartz signal approaches saturation (e.g. Chapot et al. 2012; Timar-Gabor et al. 2015a). Transferred to loess with its typical dose rate, this corresponds to an upper age limit of around 50-70 ka. Beyond this range, quartz ages can still be achieved, mainly because laboratory generated growth curves can grow 20 up to doses of more than 500 Gy (e.g. Chapot et al. 2012), but such OSL ages can be underestimated (e.g. Lai 2010; Lowick \& Preusser 2011; Chapot et al. 2012; Timar-Gabor et al. 2015a).

A further problem when dating the quartz fraction may be different ages derived from different grain sizes. This was shown by various studies in the Lower Danube region and Carpathian Basin, in which contrasting luminescence ages were determined when dating the fine $(4-11 \mu \mathrm{m})$ or coarse (63$125 \mu \mathrm{m}$ ) grain fraction of quartz in age ranges $>40 \mathrm{ka}$ (Timar-Gabor et al. 2011, 2015b; Constantin et al. 2012, 2014). In these studies, the coarse grain ages appear to provide the more reliable ages, and the fine grain ages appear to be underestimated. 
1 Furthermore, a range of studies in the recent past has shown that the thermal lifetime of the quartz 2 luminescence signal may be limited in some regions of the world (e.g. Lai \& Fan 2013; Lowick \& 3 Valla 2018). Next to saturation issues of the luminescence signal, this could be a further reason for age 4 underestimates when dating older (>100 ka) samples using quartz. However, the thermal stability of 5 the quartz luminescence signal seems to be regionally different. For example, the quartz fine grain 6 signal of Romanian loess samples has been shown to be thermally stable enough to theoretically 7 obtain ages up to $20 \mathrm{Ma}$ (Timar-Gabor et al. 2017). However, the true maximum age limit is much 8 lower, due to the limited number of electron traps.

Feldspars IRSL signals saturate at much higher doses than quartz signals. Therefore, in order to extend the age range when dating sedimentary archives, the past decade has thus seen massive improvements in feldspar dating, through the application of elevated temperature IRSL measurements (e.g. at $225{ }^{\circ} \mathrm{C}$, Buylaert et al. 2009) following a conventional IRSL measurement at $50{ }^{\circ} \mathrm{C}$ (Thomsen et al. 2008). These protocols are termed post-IR-IRSL (pIRIR) protocols, and the most commonly used ones at the moment are the MET-pIRIR (Li \& Li 2011), the pIRIR-225 (Buylaert et al. 2009), and the pIRIR-290 protocol (Thiel et al. 2011). These protocols can also be adapted to other stimulation temperatures if required by the sedimentary setting (e.g. Reimann et al. 2012; Fu \& Li 2013).

All these protocols are assumed to decrease or completely avoid fading in the high temperature measurements (e.g. Li \& Li 2011; Thiel et al. 2011; Thomsen et al. 2008; Klasen et al. 2017), making results less underestimated and less dependent on methods which correct for fading. The downside of elevated temperature IRSL measurements is the slower bleachability of the signal, which makes these methods problematic for waterlain sediments (Lowick et al. 2012). Loess however is in most cases well bleached due to its windblown nature, and it has been shown that pIRIR measurements can be applied to this archive without correcting for incomplete bleaching, such as subtracting residuals obtained through laboratory measurements (e.g. Klasen et al. 2017). An upper age limit for loess deposits at Stari Slankamen (Serbia) of around 300 ka using a pIRIR-290 protocol has been reported 
1 by Murray et al. (2014), which would make this technique applicable to loess deposited during MIS 6 2 as well as MIS 8.

3 Luminescence based chronologies of loess-paleosol sequences in the Lower Danube Region and 4 Carpathian Basin have been established mainly for Serbia, Hungary and Romania (e.g. Balescu et al. 5 2003, 2010; Fuchs et al. 2008; Antoine et al. 2009; Novothny et al. 2010, 2011; Stevens et al. 2011; 6 Timar-Gabor et al. 2011; 2015b; Vasiliniuc et al. 2012; Murray et al. 2014; Újvári et al. 2014; 7 Marković et al. 2015, 2016). Luminescence chronologies for loess sequences south of the Danube in 8 the Lower Danube Basin are so far under-represented. A detailed palaeomagnetic study has been 9 carried out at the Viatovo sequence (Jordanova et al. 2008) and through the Koriten borehole 10 (Jordanova \& Petersen 1999) in northeastern Bulgaria. Both sequences comprise thick loess deposits 11 with multiple phases of loess accumulation and soil formation down to the Brunhes-Matuyama boundary $(772 \pm 5 \mathrm{ka}$, Valet et al. 2014). Six paleosols are present, which are either of chernozem or of brown forest soil type (Jordanova et al. 2007). These paleosols are assigned to interglacial MIS 5 to 19. In both sequences only weak indication for an interstadial MIS 3 paleosol complex was found. This is in contrast to many loess sequences westward in eastern Central Europe (e.g. Hungary, Czech Republic, Serbia), which often show quite a pronounced soil development for this period (the L1S1 soil, cf. Fitzsimmons et al. 2012, locally termed e.g. the Surduk Soil in Surduk (Serbia) (Fuchs et al. 2008; Antoine et al. 2009), or the PK1 in Dolní Věstonice (Czech Republic) (Kukla 1975, Antoine et al. 2013; Fuchs et al. 2013; Rousseau et al. 2013).

Neither the Romanian sections Mostistea and Mircea Voda nor the Bulgarian sections, investigated by Jordanova et al. (2008) and Jordanova \& Petersen (1999), showed indication for the c. $40 \mathrm{ka}$ Campanian ignimbrite layer, although this tephra is widespread over other parts of Romania (Fitzsimmons et al. 2013). Indication for an older tephra was detected in Mostistea in the L2 loess unit (MIS 6) (Balescu et al. 2010). A potential correlative of this tephra is also present in Batajnica (Serbia) (Buggle et al. 2009; Marković et al. 2009) and Stalać (Serbia) (Obreht et al. 2016). 
1 In this study, we present the first luminescence chronology for a Bulgarian loess sequence, located

2 in an intermediate region between the important loess sequences of the Carpathian Basin and those of 3 the northern Lower Danube Basin. The luminescence chronology is based on quartz fine grain ages, 4 and on coarse grain feldspar multi-elevated-temperatures post-IR IRSL (MET-pIRIR) ages (Li \& Li 5 2011). The chronology is presented along with magnetic property data, which gives important 6 additional information on the intensity of pedogenesis and on a potential tephra in the sequence. The 7 chronology is discussed with regard to other well-studied loess paleosol sequences in the Carpathian 8 Basin and Lower Danube region.

\section{$9 \quad$ Study area}

The loess sequence of Harletz $\left(43^{\circ} 41^{\prime} 53^{\prime \prime} \mathrm{N}, 23^{\circ} 49^{\prime} 43^{\prime \prime}\right.$ E) is located on the western bank of the Ogosta River valley, a small tributary to the Danube, flowing in from the southwestern Chiprovska Mountain range (Fig. 1). The distance of the site to the Danube is about $7 \mathrm{~km}$. The Ogosta valley is deeply incised into thick plateau loess deposits. Dry oxbows attest to the former meandering character of the river.

Today's climate is continental, with average annual temperatures of $11{ }^{\circ} \mathrm{C}$, January temperatures of $-2{ }^{\circ} \mathrm{C}$, and July temperatures of $23{ }^{\circ} \mathrm{C}$ (Fotakiewa \& Minkov 1966). Precipitation ranges between $500-600 \mathrm{~mm}$ per year with a maximum in the summer months. The typical modern soil type is the chernozem. Thick paleosols, with characteristics of forest soil type, indicate more humid condition in past interglacials (Jordanova et al. 2008).

According to Evlogiev (2000), the loess deposits in North Bulgaria cover Pleistocene river terraces, or older (Pliocene) denudation and accumulation surfaces. Fluvial terraces in the Bulgarian part of the Danube plain are numbered from T0 to T6, with T0 being the youngest (Holocene) terrace. Terrace T1 carries one loess unit, T6 has six loess units separated by paleosols (Evlogiev 1993 in Jordanova et al. 2008). Profile excavation and preparation revealed two distinct loess units in our investigated sequence, divided by one thick paleosol, suggesting that it rests on terrace T2. 


\section{Stratigraphy}

2 The Harletz sequence is naturally exposed due to a river cutting within a former meander belt. $20 \mathrm{~m}$ of 3 the natural outcrop were cleaned by removing the weathered material following Antoine et al. (1999)

4 protocol, exposing the base of the loess layers and underlying alluvial sediments. The sequence was 5 divided into 14 main stratigraphical units. A short description of each unit is presented in Table 1. The 6 schematic display of the sequence, together with magnetic susceptibility measured in the field $\left(\kappa_{\mathrm{FIELD}}\right)$ 7 and in the laboratory $(\chi)$ is shown in Fig. 2.

8 In general, the stratigraphy of the Harletz loess sequence can be described as the following. The 9 basal part of the loess sequence (Unit 12 -14) mainly consists of sandy to clayey overbank deposits, 10 which are strongly overprinted by pedogenesis. The overlying units (Unit $4-11$ ) are represented by 11 loess layers intercalated with thin, incipient paleosols, yielding varying magnetic susceptibility values. 12 Unit $3 \mathrm{~b}$ shows unaltered loess with low magnetic susceptibility and Unit 3a represents a transition 13 zone from unaltered loess to the overlying paleosol complex, already showing rising magnetic 14 susceptibility values. The older loess unit is overlain by a prominent paleosol complex (Unit $2 \mathrm{a}$ and 15 2b) with high magnetic susceptibility. The younger loess units (Units 1d-1a) contain a weakly 16 developed paleosol (mainly in Unit 1c and in the lower part of Unit 1b), which is hardly noticed in the 17 field but is well represented by the higher magnetic susceptibility values than in the unaltered loess layers. The uppermost unit (Unit 0) is represented by the current soil (in situ Ah horizon of a chernozem).

\section{Magnetic properties}

The in-field volume-specific magnetic susceptibility $\left(\kappa_{\text {FIELD }}\right)$ was measured with a handheld KT-6 Kappameter from SatisGeo (Brno, Czech Republic) every $10 \mathrm{~cm}$ along the 20 meters of the section. Five measurements were acquired evenly spaced across an approximate one-meter width at each stratigraphic interval, averaged and its standard deviation calculated. Laboratory measurements of the 
1 mass-specific magnetic susceptibility $(\chi)$ was analysed on a Bartington MS2B dual frequency bridge

2 in the paleomagnetism laboratory at the Bulgarian Academy of Science in Sofia. The MS2B bridge 3 operates with a field amplitude of $200 \mathrm{~A} / \mathrm{m}$ and at frequencies of $465 \mathrm{~Hz}$ and $4650 \mathrm{~Hz}$. The low-

4 frequency values are reported as the mass specific magnetic susceptibility $(\chi)$ (Fig. 2). The difference

5 between $\chi$ measured at low- and high-frequency defines the absolute frequency dependence of 6 magnetic susceptibility $\left(\Delta \chi_{\mathrm{FD}}\right)$. Variations in $\Delta \chi_{\mathrm{FD}}$ are dominantly due to changes in relative

7 concentration of fine $(\sim 20-30 \mathrm{~nm})$ magnetic particles considered to be of pedogenic origin (Maher \&

8 Taylor 1988; Zhou et al. 1990). The large-scale variations observed in the $\kappa_{\text {FIELD }}$ data are reproduced in 9 the higher resolution laboratory data. However, the laboratory data reveals an important stratigraphic detail absent in $\kappa_{\text {FIELD }}$ data and in the profile's field observation log. A sharp peak in $\chi$ is revealed at $12.10-12.00 \mathrm{~m}$ depth, just above unit 4. $\Delta \chi_{\mathrm{FD}}$ does not increase over this interval suggesting that a pedogenic process is not at the origin of the abnormally high value with respect to the surrounding 
1 treatment with $\mathrm{HCl}$ and $\mathrm{H}_{2} \mathrm{O}_{2}$, the coarse-grain felspar fraction was extracted using heavy density

2 liquid $\left(<2.68 \mathrm{~g} \mathrm{~cm}^{-3}\right)$. No HF etching step was applied to the coarse grain-feldspar fraction. The quartz

3 fine-grain fraction was separated by settling using Stokes' law. To obtain the quartz rich fraction, the

4 polymineral samples were etched in $34 \%$ pre-treated $\mathrm{H}_{2} \mathrm{SiF}_{6}$ for several days. All measurements were

5 performed on a Lexsyg Research Luminescence reader (Lomax et al. 2014).

6 Radionuclide concentrations of $\mathrm{U}$ and $\mathrm{Th}$ were determined using alpha counting and $\mathrm{K}$ 7 concentrations using ICP-OES. These analyses were carried out at the University of Bayreuth 8 (Department of Geography). The determination of the dose rate is based on conversion factors of 9 Guérin et al. (2011), and consideration of the cosmic dose following Prescott and Hutton (1988, 10 1994). For the quartz fine grain fraction an $a$-value of $0.04 \pm 0.01$ (Rees-Jones 1995), and for the 11 feldspar coarse grain fraction, an $a$-value of $0.09 \pm 0.02$ (Balescu et al. 2007) was considered. For the 12 feldspar coarse grain fraction, an internal K content of $12.5 \pm 0.5 \%$ was applied (Huntley \& Baril 1997). 13 Water contents were estimated for the samples based on a combination of grain size distribution and 14 values measured in the laboratory. With this approach, dose rates of the loess samples were calculated 15 with lower water contents $(12 \pm 7 \%)$ than samples from soil horizons $(15 \pm 7 \%)$, and from the clay rich 16 alluvium at the base of the sequence $(20 \pm 7$ and $25 \pm 7 \%)$. Dose rate calculations were performed with 17 the DRAC program published by Durcan et al. (2015). Dose rate data including water contents can be 18 found in Table 3.

Fine grain quartz dating

The fine grain quartz fraction was pipetted onto stainless steel cups, approximating $1 \mathrm{mg}$ of material per cup. The samples were stimulated with green LEDs $\left(525 \pm 25 \mathrm{~nm}, 70 \mathrm{~mW} \mathrm{~cm}{ }^{-2}\right)$ for 50 seconds at $125^{\circ} \mathrm{C}$ (Murray \& Wintle 2000), and integration limits were set to 0-0.5 s (initial signal) and 40-50 s (signal background). Luminescence signals were filtered through an HC377/50 (5 mm) + BG3 (3 mm) filterset, and monitored with a Hamamatsu photomultiplier tube (H7360). This filter combination restricts the detected wavelength to $\sim 350-400 \mathrm{~nm}$, encompassing the peak OSL emission of quartz (Huntley et al. 1991; Lomax et al. 2015). For testing potential feldspar contamination, IR laser diodes 
$1(850 \pm 3 \mathrm{~nm})$ and a filter combination with a Semrock HC414/46 and a Schott BG39 were used.

2 Irradiation was performed with a Sr-90 $\beta$-source, delivering a dose rate of $\sim 0.13$ Gy s ${ }^{-1}$ to fine grain

3 quartz samples. This value was verified by measuring fine grain quartz calibration samples.

4 The quartz coarse grain fraction was also tested for its suitability for age determination. This 5 fraction yielded a large scatter in saturation behaviour and in resulting equivalent dose $\left(D_{e}\right)$ values, as 6 well as underestimated $D_{e}$ values (in comparison to the quartz fine grain and feldspar coarse grain

7 fraction). This behaviour is exemplarily shown in Fig. 3, presenting the dose response curves of four 8 aliquots of sample GI05. Measurement were performed using a conventional Single Aliquot 9 Regenerative Dose (SAR) protocol (Murray \& Wintle, 2000, 2003) with a preheat-cutheat temperature of $220-200{ }^{\circ} \mathrm{C}$. The analysis resulted in an overdispersion of $19 \%$ for the four $\mathrm{D}_{\mathrm{e}}$ values (mask size of

$114 \mathrm{~mm}$ ). Very striking is the different saturation behaviour, with one aliquot saturating already at 12 around $100 \mathrm{~Gy}$, and another aliquot showing no onset of saturation even at around $200 \mathrm{~Gy}$. A dose recovery test was also performed for this grain size, which yielded an unsatisfactory dose recovery ratio (recovered/given dose) of $0.92 \pm 0.05(n=8)$. This behaviour of underestimated dose recovery tests and of strongly different saturation levels was neither seen in the fine grain quartz nor coarse grain feldspar fraction. For these reasons, the quartz coarse grain fraction of all the samples was not 17 further analysed.

$D_{e}$ values of the fine grain quartz fraction were measured using a conventional SAR with four to five regeneration doses, a zero dose, and one recycling dose. A typical growth curve and typical OSL shine down curve are shown in Fig. 4A, B. Figure 4B also shows the IRSL response to a dose of 21 Gy, demonstrating that there is negligible feldspar contamination in the quartz fine grain fraction.

Preheat conditions were determined on the base of preheat plateau tests (PHT), and combined preheat-dose recovery tests (PHT-DRT). Results of these tests are shown in Fig. S1. The PHT shows a trend in decreasing $\mathrm{D}_{\mathrm{e}}$ values with increased stimulation temperatures. It is thus difficult to detect a plateau region. In contrast, when measuring known artificial doses in the PHT-DRT, the recovered 
1 standard measurements, a preheat-cutheat temperature combination of $220-200{ }^{\circ} \mathrm{C}$ was chosen. These 2 preheat conditions are similar to preheat-cutheat temperatures of $220-180{ }^{\circ} \mathrm{C}$ chosen by Timar-Gabor 3 et al. $(2011,2012)$ for their samples from nearby sites in Mostistea and Mircea Voda (Romania). 4 However, their samples were stimulated with blue LEDs.

5 Standard rejection criteria such as a recycling ratio of $>10 \%$ and a recuperation value of $<10 \%$ of 6 the natural signal were applied when analysing the measurements. None of the measured aliquots 7 needed to be rejected for poor recuperation behaviour or recycling ratio. Average recycling ratios for 8 all samples ranged between 0.96 and 1.01, with an overall average of 0.99 . As expected from fine 9 grain aliquots where millions of grains are measured at the same time, signal averaging lead to low 10 overdispersion values between 0 and $4.8 \%$ for all samples. This resulted in the application of the 11 Central Age Model (Galbraith et al. 1999) as mode of the mean $D_{e}$ calculation. In case of an 12 overdispersion of $0 \%$, the model reduces to the Common Age Model, stating that all observed scatter of $\mathrm{D}_{\mathrm{e}}$ values can be explained by photon counting statistics and instrumental variablility alone.

Growth curves were fitted with a saturating exponential plus linear function. The linear component is very pronounced in the high dose region, suggesting potential $D_{e}$ determination up to at least 420 Gy. However, previous studies have observed this growth behaviour for other quartz fine grain samples, and have come to the conclusion that it may lead to $\mathrm{D}_{\mathrm{e}}$ and age underestimation (e.g. Lowick et al. 2010; Lowick \& Preusser 2011; Kreutzer et al. 2012; Timar-Gabor et al. 2017).

In order to gain more information on the saturation level of the quartz fine grain samples, extended dose recovery tests (DRTs) were performed on the quartz fraction (Duller 2012; Lowick et al. 2015).

21 For these tests, samples were bleached in the Lexsyg reader using green LEDs $\left(70 \mathrm{~mW} \mathrm{~cm}{ }^{-2}\right)$ at 125 ${ }^{\circ} \mathrm{C}$ for $100 \mathrm{~s}$. Subsequently, five sets of samples consisting of three aliquots each were irradiated with known doses of 244, 305, 366, 427, 488 and 549 Gy. These doses were then attempted to be recovered with the same SAR protocol used for the standard measurements. Results indicate that doses of 305 Gy and higher are systematically underestimated but are still in the range of $10 \%$ deemed acceptable in DRTs (Murray \& Wintle 2003) (Fig. 5). Also noted in Fig. 5 is the maximum dose level of the 
Coarse grain feldspar dating

1 natural samples GI12 to GI20, hence all samples below the prominent paleosol. These samples all

2 yield $D_{e}$ values between 330 and $350 \mathrm{~Gy}$, although they would be expected to have $\mathrm{D}_{\mathrm{e}}$ values of more

3 than 500 Gy. It thus appears that in artificially irradiated samples, doses of 500 Gy can be achieved,

4 but not in the natural samples. This behaviour is in agreement with previous studies carried out by e.g.

5 Chapot et al. (2012) and Timar-Gabor et al. (2015a), who found that natural dose response curves

6 saturate much earlier than laboratory generated dose response curves. It has also been shown in the

7 past that quartz signals from different regions such as the Alpine Foreland or the Chinese loess plateau

8 may suffer from thermal instability, which can lead to age underestimations (e.g. Lai \& Fan 2014;

$9 \quad$ Klasen et al. 2016; Lowick \& Valla 2018). Since our study area in Bulgaria is very close to the study areas of Timar-Gabor et al. (2015a), we tentatively adopt the saturation level obtained in their study for fine grained quartz of $\sim 200 \mathrm{~Gy}$, based on natural dose response curves. Considering the dose rates, this translates to an upper age limit of around 60-70 ka for our quartz samples. Beyond this limit, ages can be obtained but are assumed to be underestimates.

Given the potential underestimation of the older quartz fine grain ages, the MET-pIRIR protocol of Li \& Li (2011) was applied to a selected set of coarse grain feldspar samples. The protocol of $\mathrm{Li} \& \mathrm{Li}$ (2011) uses consecutively higher stimulation temperatures, ranging from $50{ }^{\circ} \mathrm{C}$ to 250 (or 300 ) ${ }^{\circ} \mathrm{C}$. Ideally, the resulting $\mathrm{D}_{\mathrm{e}}$ values form a $\mathrm{D}_{\mathrm{e}}$-plateau, for which it is assumed that it is based on a stable, non-fading luminescence signal.

The feldspar coarse grain fraction was mounted onto stainless steel cups using a mask size of $2 \mathrm{~mm}$ diameter. All measurements were carried out on a Lexsyg Reader using stimulation through IR laser diodes $\left(830 \pm 3 \mathrm{~nm}, 300 \mathrm{~mW} \mathrm{~cm}{ }^{-2}\right)$ and signal detection through an interference filter centred at 410 $\mathrm{nm}$. Signals were stimulated for $200 \mathrm{~s}$ at each different temperature step. Integration limits were set to the first second for the initial signal, subtracted by a background signal measured at the last 40 seconds of signal detection. The protocol of $\mathrm{Li} \& \mathrm{Li}$ (2011) was slightly modified in this study, by using a 
1 slightly lower hot bleach temperature of $290{ }^{\circ} \mathrm{C}(100 \mathrm{~s})$ instead of $320{ }^{\circ} \mathrm{C}$, and a lower preheat 2 temperature of $270{ }^{\circ} \mathrm{C}(60 \mathrm{~s})$ instead of $300{ }^{\circ} \mathrm{C}$. This adjustment was made because it has been shown 3 in the past that high preheat temperatures $\left(>300{ }^{\circ} \mathrm{C}\right)$ used in pIRIR protocols can cause an 4 overestimation of the $D_{e}$ (Roberts 2012). Stimulation temperatures were set at 50, 100, 150, 200 and $5250{ }^{\circ} \mathrm{C}$, following the original protocol of $\mathrm{Li} \& \mathrm{Li}(2011)$.

6 Dose recovery test, fading experiment and residual measurements. - Residual doses were measured 7 after exposing sample GI07 and sample GI11 to full sunlight for 3 hours. Residual doses for both 8 samples and the respective stimulation temperatures of the MET-pIRIR protocol are listed in Table 2. 9 Surprisingly, the residual doses of the two samples are very similar, despite the different natural doses of 220 Gy in sample GI07 and 500 Gy in sample GI11. When transferred into ages (by dividing the residual doses by a typical dose rate of $3.4 \mathrm{~Gy} \mathrm{ka}^{-1}$ ), this corresponds to ages of a maximum of c. $7 \mathrm{ka}$, when using the highest stimulation temperature of $250^{\circ} \mathrm{C}$. This may lead to significant age overestimation in Late Pleistocene samples but becomes less significant for Middle Pleistocene samples. However, it is assumed that bleaching in nature is much longer than the 3 hours applied in our test. Non-bleached residuals are therefore most likely not an issue for the samples investigated in this study, irrespective of stimulation temperature in the MET-pIRIR protocol.

The same aliquots used in the residual dose test were subsequently irradiated and used for a dose recovery test in sample GI07. A dose of 260 Gy was administered, and dose recovery ratios (i.e. recovered/administered dose) of $0.97 \pm 0.03\left(50{ }^{\circ} \mathrm{C}\right), 1.02 \pm 0.09\left(100{ }^{\circ} \mathrm{C}\right), 0.99 \pm 0.04\left(150{ }^{\circ} \mathrm{C}\right)$, $1.02 \pm 0.09\left(200{ }^{\circ} \mathrm{C}\right)$, and $1.06 \pm 0.10\left(250{ }^{\circ} \mathrm{C}\right)$ were observed. The MET-pIRIR protocol is thus able to recover a known beta dose, irrespective of the stimulation temperature. Furthermore, a fading test based on Auclair et al. (2003), adapted to the MET-pIRIR protocol was applied to test for fading rates in relation to the stimulation temperature. Three aliquots ( $2 \mathrm{~mm}$ mask size) of sample GI09 were prepared by bleaching the natural signal in the Lexsyg reader and subsequently giving regeneration doses of $300 \mathrm{~s}$, followed by test doses of $100 \mathrm{~s}$. Different storage times up $24 \mathrm{~h}$ were inserted between application of the preheat temperature and measurement of the respective IRSL signals. Results of these tests are shown in Fig. S2. As expected, the signals measured at a stimulation temperature of 50 
$1{ }^{\circ} \mathrm{C}$ show the highest fading rate, with a g-value of $3.8 \pm 0.2 \%$ per decade. Signals measured at 100,150 , 2 and $200{ }^{\circ} \mathrm{C}$ show low fading rates with g-values between $1.0 \pm 0.4$ and $-1.5 \pm 0.8 \%$ per decade, and 3 signals measured at $250{ }^{\circ} \mathrm{C}$ show a strong negative fading rate with a g-value of $-2.8 \pm 0.9 \%$ per decade.

4 The latter might be explained by a laboratory artefact and/or the relatively low precision due to dim 5 signals when stimulating the signals with this temperature. Based on the test, $D_{e}$ values based on stimulation temperatures between 100 and $200{ }^{\circ} \mathrm{C}$ appear acceptable, showing little or negative fading rates, which can be treated as laboratory artefacts.

Analyses of $D_{e}$ versus stimulation temperature in the MET-pIRIR protocol. - Fig. 6 shows $\mathrm{D}_{\mathrm{e}}$ values of the analysed samples in relation to the stimulation temperatures. Also shown is the expected dose according to the quartz fine grain measurements of sample GI05 and GI07. It is observed that only sample GI05 and GI09 show an obvious plateau. Most of the other samples show constantly rising $\mathrm{D}_{\mathrm{e}}$ values with increasing stimulation temperature, although there is a slowing of the increase of $D_{e}$ values in the region from 100 to $200{ }^{\circ} \mathrm{C}$ for many samples. For the two samples which still yield reliable quartz $\mathrm{D}_{\mathrm{e}}$ values (GI05 and GI07) the $\mathrm{D}_{\mathrm{e}}$ values which result from the $250{ }^{\circ} \mathrm{C}$ and from the $200{ }^{\circ} \mathrm{C}$ stimulation temperature seem to be overestimated when compared to the dose expected from the quartz fine grain measurements. A possible explanation for the overestimated $D_{e}$ values at the two high stimulation temperatures could be unnoticed sensitivity changes before measurement of the natural signal, which would not be detected either in a dose recovery test nor by the recycling ratio. This behaviour was observed by e.g. Roberts (2012) and Vasiliniuc et al. (2012) and was cited as causing overestimated $D_{e}$ values when using high temperature protocols such as the pIRIR-290 protocol (Thiel et al. 2011). Unbleachable residuals and/or incomplete bleaching as another potential reason for the rising $D_{e}$ values with increasing stimulation temperatures we rule out as the main reason, because our bleaching test showed only little differences in the size of the residuals at the different stimulation temperatures.

Because it is hard to choose the correct feldspar $D_{e}$ value independently (thus only from the feldspar measurements based on a $D_{e}$ plateau), we decided to make use of the comparison with the $D_{e}$ expected from the quartz fine grain measurements. We consider the quartz $D_{e}$ values reliable in the 
1 two youngest samples (GI05 and GI07). When transferring this to the feldspar measurements by

2 considering the slightly higher dose rates of the feldspar coarse grains, a stimulation temperature of

3100 or $150^{\circ} \mathrm{C}$ seems best suited. This result is supported by the low fading rates determined for these

4 stimulation temperatures. All feldspar ages reported in the following and shown in Table 3 as well as

5 in Fig. 2 are based on a stimulation temperature of $150^{\circ} \mathrm{C}$, and were not corrected for fading.

6 For the stimulation temperature of $150{ }^{\circ} \mathrm{C}$, average recycling ratios between 0.95 and 0.99 were

7 obtained, with an overall average of 0.98 , and no aliquots with recycling ratios $>10 \%$ needed to be

8 rejected. Overdispersion values ranged between 3.1 and 11.4\%, justifying the use of the Central Age

9 Model (Galbraith et al. 1999) as mode of mean $D_{\mathrm{e}}$ calculation.

10

\section{Luminescence ages}

Luminescence ages for the quartz fine grain fraction are shown in Table 3 and in Fig. 2. Note that for three samples (GI06, GI13 and GI16), there was not enough material left after etching for OSL measurements. It is assumed that the quartz ages for the upper part of the sequence (Unit 1a-d, GI05 and GI07) are reliable, and that all older ages are underestimated, since doses in these samples exceed the saturation level of 200 Gy provided by Timar-Gabor et al. (2015a).

The two uppermost feldspar ages agree within errors with the quartz ages. As mentioned above, these feldspar ages were deliberately matched with the quartz ages, and are thus not totally independent. Down to Unit 3b, the feldspar ages are in correct chronostratigraphic order and appear to make sense from a pedostratigraphic point of view. Sample GI13 and GI17 show a slight inversion of ages, with GI17 appearing underestimated. With regard to the lowermost sample GI20, both overlying samples agree within errors though.

\section{Discussion}

Based on the methodological considerations we preliminarily assigned the uppermost loess layer and the weakly developed paleosol to MIS 4 (Unit 1d), and MIS 3 (Units 1c and 1b), the prominent 
1 paleosol to MIS 5 (Units 2b-2a) and the underlying loess unit as well as the alluvial base of the

2 sequence to MIS 6 (Units 3a-14). Following this interpretation, we try to compare the loess and 3 paleosol layers to other sequences nearby (Lower Danube plain) and further to the west in the 4 Carpathian Basin, in order to further secure the established chronology by stratigraphic correlation.

5 The main sequences used for the correlation including their luminescence chronology are shown in 6 Fig. 7.

7

8

\section{Youngest loess unit including weakly developed interstadial paleosol (L1 and L-S1)}

The uppermost loess layer was accumulated around 60 to $40 \mathrm{ka}$. Presumably, more loess was accumulated during MIS 2, but this part of the sequence has been most likely subject to strong erosion by human agricultural activities. In addition, during MIS 2, the sediment trap formed by the junction between the steep slope and the alluvial plain on the left bank of the Ogosta River was already filled by previous loess deposition. The weakly developed paleosol is recognised in the magnetic susceptibility but hardly results in a visible colour change in the field. Based on the luminescence ages, it must have formed before $40 \mathrm{ka}$, thus at least in the middle or early part of MIS 3 . In the Danube Plain (Bulgaria and Romania), this paleosol seems widespread, but equally weakly developed. It is recognised in Koriten and Viatovo by slightly increased magnetic susceptibility values (Jordanova \& Petersen 1999; Jordanova et al. 2008). At Viatovo, the MIS 3 paleosol nearly directly merges into the modern S0 (Jordanova et al. 2008), indicating erosion of parts of the MIS 2 loess such as in the Harletz sequence. The weakly developed paleosol was also detected in the Romanian loess sequences of Tuzla and Mircea Voda, by means of field observations, magnetic susceptibility values and constraining luminescence ages (Balescu et al. 2003, 2010; Buggle et al. 2009; Timar et al. 2010) but is not as obvious in the Romanian sequence Mostistea (Balescu et al. 2010). In the latter section, this paleosol is possibly eroded or so close to the surface (due to erosion of the MIS 2 loess) that it is overprinted by the Holocene soil formation. To the west of the Carpathians, the MIS 3 paleosol appears more prominent, of greater thickness and, at Surduk, of greater complexity (e.g. Fuchs et al. 
1 2008; Antoine et al. 2009; Újvári et al. 2014). Here, the paleosol complex seems to have developed 2 between about $55 \mathrm{ka}$ and $35 \mathrm{ka}$ during the Middle Pleniglacial chronoclimatic phase.

3 At Harletz, the Campanian ignimbrite layer was not observed through magnetic susceptibility data.

4 The tephra was distributed in south and southeastern Europe shortly after $40 \mathrm{ka}$ (De Vivo et al. 2001;

5 Fitzsimmons et al. 2013) due to the eruption of the Phlegraean Fields (Italy). Local thickness at other

6 sites in Romania was found to be up to $80 \mathrm{~cm}$ (Veres et al. 2013). The reason for not detecting this

7 tephra in Harletz is most likely erosion of this part of the sequence. In summary, loess deposition in

8 MIS 4 and 3, and a weakly developed MIS 4/MIS 3 interstadial paleosol are widespread features in the

9 Danube Plain. Also common is the strong erosion of probably accumulated MIS 2 loess, possibly

10 including erosion of the Campanian ignimbrite layer as well.

Paleosol complex (S1)

The prominent paleosol complex at 6-4 m below the modern top surface (Unit 2) yields magnetic susceptibility values which are around three time higher than those of the weakly developed paleosol at about $2.5 \mathrm{~m}$ and nearly twice as high as those of the modern soil. The paleosol is bracketed by luminescence ages in the over- and underlying loess units of $63 \pm 6$ and $141 \pm 13 \mathrm{ka}$, which probably places it into MIS 5. From the luminescence ages within the soil complex, ranging between around 70 and $90 \mathrm{ka}$ (MIS 5a-5b), it seems that the soil formation falls into the later part of this marine isotope stage. In this regard, it needs to be reminded that luminescence does not date the soil formation, but the loess accumulation before the proper soil development, or the colluvial deposition of particles in the case of upbuilding soils like those occurring in the MIS 5 Early Glacial soil complexes (Antoine et al. 2016). On the other hand, bioturbation in soils, especially in chernozems may be strong and may lead to rejuvenation of loess layers due to bleaching of the luminescence signal through burrowing activities near the surface (e.g. Bateman et al. 2003). Based on our results, it is not totally clear, if the paleosol is an interglacial soil sensu lato (MIS 5), or even sensu stricto (MIS 5e). Usually, studies based on magnetic susceptibility roughly place this paleosol into MIS 5. Luminescence ages determined in other sequences yield values which seem "too young", thus loess deposition in middle 
1 or late MIS 5 within the paleosol, such as in Hungary (Novothny et al. 2010, 2011; Újvári et al. 2014).

2 Other studies did not sample the paleosol complex itself, but yielded luminescence ages of about 105

3 to $125 \mathrm{ka}$ in the directly underlying loess (e.g. Fuchs et al. 2008, 2013; Stevens et al. 2011).

4

5

6 The loess unit underlying the prominent paleosol complex dates to c. 130 to $185 \mathrm{ka}$, based on the 7 feldspar MET-pIRIR ages, hence can be assigned to MIS 6. Numerous other studies within the 8 Carpathian and Lower Danube Basin equally assigned this loess unit to MIS 6 or early MIS 5, either 9 based on luminescence ages or on magnetic susceptibility variations (e.g. Jordanova \& Petersen 1999;

\section{Older loess unit (L2)} Jordanova et al. 2008; Fuchs et al. 2008; Buggle et al. 2009; Marković et al. 2009; Balescu et al. 2010; Novothny et al. 2010, 2011; Stevens et al. 2011; Timar-Gabor et al. 2011; Vasiliniuc et al. 2012; Murray et al. 2014; Újvári et al. 2014). In the nearby sequence of Viatovo (Bulgaria), the loess is described as a unit with low secondary alterations and bioturbation (Jordanova et al. 2008). In several other loess sequences in southeastern Europe, a tephra was discovered in the L2 loess unit; e.g. in Batajnica, Ruma and Stalać in Serbia (Buggle et al. 2009; Marković et al. 2009, Vandenberghe et al. 2014; Obreht et al. 2016), and at Mostistea in Romania (Balescu et al. 2010; Panaiotu et al. 2001). A potential tephra in this loess unit is also detected at Harletz. Potentially, the tephra of these sequences is of the same origin, and may serve as important marker for further investigations. In this study, it was dated to $>171 \pm 14$, and at Mostistea, to between $132 \pm 14$ and $171 \pm 22$ (Balescu et al. 2010). Obreht et al. (2016) also place it to around 175 ka in Ruma and Stalać, based on their age model and magnetic susceptibility data. As it is so thin, it requires high resolution sampling to be detected.

Based on the feldspar MET-pIRIR ages, the alluvial base of the sequence would be assigned to MIS 6. However, the soil complex at the base of the sequence exhibits both in field and thin sections pedological features typical of interglacial conditions and some shells of land snails typical for 
1 arboreal vegetation (Cepaea sp.), arguing for an assignment to MIS 7 . If this is the case, then the

2 luminescence ages are underestimated.

3

\section{Conclusions}

5 The application of the SAR protocol to the quartz fine grain fraction led to age underestimation for the 6 lower part of the sequence, as commonly shown in other loess studies from many regions. Thus the $7 \quad$ MET-pIRIR protocol was applied to the coarse grain feldspar fraction. As laboratory tests yielded low 8 fading rates for the elevated stimulation temperatures of 100,150 and $200{ }^{\circ} \mathrm{C}$, and as laboratory 9 bleaching tests yielded low residual doses, the MET-pIRIR protocol seems applicable to the loess sequence at Harletz. The loess sequence inculdes a MIS 3 weakly developed paleosol, a MIS 3-4 loess unit, a MIS 5 Interglacial/Early Glacial paleosol complex, and a thick $( \pm 10 \mathrm{~m})$ underlying MIS 6 loess unit. At the base, even the pIRIR luminescence ages appear underestimated from a stratigraphical point of view. Two main further conclusions can be drawn from the chronostratigraphy and may be of importance for future investigations in the area.

- The potentially accumulated MIS 2 loess layer seems to be completely or partially eroded or was not deposited at Harletz. This needs to be cautiously considered when analysing other loess sequences without applying numerical dating, such as magnetic susceptibility.

- Like in Mostistea, Batajnica, Ruma and Stalać, the L2 loess unit includes a tephra layer, which may serve as an important marker horizon in future studies. However, more information on this tephra, such as a mineralogical characterisation and an individually determined age and origin, are required.

Acknowledgements. - We would like to thank Marcel Hude for sample preparation, Manfred Fischer for carrying out measurement of radionuclide concentrations and Lisett Diehl for help with the figures. This is contribution number 3956 of IPGP, and 8237 of LDEO. We would also like to express our gratitude to Mark Bateman and a further anonomous reviewer for substantially improving an earlier version of the manuscript. This study was supported by Grant ANR-08-BLAN-0227 from Agence 
Nationale de la Recherche to D.-D.R. (project "ACTES"), by the CNRS-INSU SYSTER program through grant 2012-31124A to F.L. and the PHC Rila program through project \#34286QB to F.L. and D.J.

\section{References}

Antoine, P., Rousseau, D.-D., Fuchs, M., Hatté, C., Gauthier, C., Marković, S. B., Jovanovic, M., Gaudenyi, T., Moine, O. \& Rossignol, J. 2009: High-resolution record of the last climatic cycle in the southern Carpathian Basin (Surduk, Vojvodina, Serbia). Quaternary International 198, $19-36$.

Antoine, P., Rousseau, D.-D., Degeai, J.-P., Moine, O., Lagroix, F., Kreutzer, S., Fuchs, M., Hatté, C., Gauthier, C., Svoboda, J. \& Lisa, L. 2013: High-resolution record of the environmental response to climatic variations during the Last Interglacial-Glacial cycle in Central Europe: the loesspaleosol sequence of Dolní Věstonice (Czech Republic). Quaternary Science Reviews 67, $17-38$.

Antoine, P., Coutard, S., Guérin, G., Deschodt, L., Goval, E., Locht, J.-L. \& Paris, C. 2016: Upper Pleistocene loess-paleosols records from Northern France in the European context: environmental background and dating of the Middle Palaeolithic. Quaternary International 411, 4-24.

Auclair, M., Lamothe, M.\& Huot, S. 2003: Measurement of anomalous fading for feldspar IRSL using SAR. Radiation Measurements 37, 487-492.

22

Balescu, S., Lamothe, M., Mercier, N., Huot, S., Balteanu, D., Billard, A. \& Hus, J. 2003: Luminescence chronology of Pleistocene loess deposits from Romania: testing methods of age correction for anomalous fading in alkali feldspars. Quaternary Science Reviews 22, 967-973.

Balescu, S., Lamothe, M., Panaiotu, C. \& Panaoitu, C. 2010: La chronologie IRSL des séquences loessiques de l'est de la Roumanie. Quaternaire 21, 115-126. 
1 Balescu, S., Ritz, J.-F., Lamothe, M., Auclair, M. \& Todbileg, M. 2007: Luminescence dating of a

2

3

4

5

6

7 gigantic palaeolandslide in the Gobi-Altay mountains, Mongolia. Quaternary Geochronology 2, $290-295$.

Bateman, M. D., Frederick, C. D., Jaiswal, M. K. \& Singhvi, A. K. 2003: Investigations into the potential effects of pedoturbation on luminescence dating. Quaternary Science Reviews 22, $1169-1176$.

Buggle, B., Hambach, U., Glaser, B., Gerasimenko, N., Marković, S., Glaser, I. \& Zöller, L. 2009: Stratigraphy, and spatial and temporal paleoclimatic trends in Southeastern/Eastern European loess-paleosol sequences. Quaternary International 196, 86-106.

Buylaert, J., Murray, A., Thomsen, K. \& Jain, M. 2009: Testing the potential of an elevated temperature IRSL signal from K-feldspar. Radiation Measurements 44, 560-565.

Chapot, M. S., Roberts, H. M., Duller, G. A. T. \& Lai, Z.-P. 2012: A comparison of naturally and laboratory-generated dose response curves for quartz optically stimulated luminescence signals from Chinese loess. Radiation Measurements 47, 1045-1052.

Constantin, D., Timar-Gabor, A., Veres, D., Begy, R. \& Cosma, C. 2012: SAR-OSL dating of different grain-sized quartz from a sedimentary in southern Romania interbedding the Campanian Ignimbrite/Y5 ash layer. Quaternary Geochronology 10, 81-86.

Constantin, D., Begy, R., Vasiliniuc, S., Panaiotu, C., Necula, C., Codrea, V. \& Timar-Gabor, A. 2014: High-resolution OSL dating of the Costinesti section (Dobrogea, SE Romania) using fine an coarse quartz. Quaternary International 334-335, 20-29.

Duller, G. A. T. 2012: Improving the accuracy and precision of equivalent doses determined using the optically stimulated luminescence signal from single grains of quartz. Radiation Measurements 47, 770-777.

Durcan, J. A., King, G. E. \& Duller, G. A. T. 2015: DRAC: Dose Rate and Age Calculator for trapped charge dating. Quaternary Geochronology 28, 54-61. 
1 Evlogiev, J. 1993: Palaeogeography and stratigraphy of the Early Pleistocene in near Danube

2 Northeastern Bulgaria. Ph.D. thesis, Bulgarian Academy of Sciences, 265 pp.

Evlogiev, J. 2000: The Quaternary in Northeast Bulgaria. Review of the Bulgarian Geological Society $61,3-25$.

Fitzsimmons, K. E., Hambach, U., Veres, D., Iovita, R. \& Hart, J. P. 2013: The Campanian ignimbrite eruption: new data on volcanic ash dispersal and its potential impact on human evolution. PLoS ONE 8, 1-13.

Fitzsimmons, K. E., Marković, S. B. \& Hambach, U. 2012: Pleistocene environmental dynamics recorded in the loess of the middle and lower Danube basin. Quaternary Science Reviews 41, $104-118$.

Fotakiewa, E. \& Minkov, M. 1966: Der Löß in Bulgarien. Eiszeitalter und Gegenwart 17, 87-96.

Fu, X. \& Li, S.-H. 2013: A modified multi-elevated-temperature post-IR IRSL protocol for dating Holocene sediments using K-feldspar. Quaternary Geochronology 17, 44-54.

Fuchs, M., Kreutzer, S., Rousseau, D.-D., Antoine, P., Hatté, C., Lagroix, F., Moine, O., Gauthier, C., Svoboda, J. \& Lisá, L. 2013: The loess sequence of Dolní Věstonice, Czech Republic: A new OSL-based chronology of the Last Climatic Cycle. Boreas 42, 664-677.

Fuchs, M., Rousseau, D.-D., Antoine, P., Hatté, C., Gauthier, C., Marković, S. \& Zoeller, L. 2008: Chronology of the Last Climatic Cycle (Upper Pleistocene) of the Surduk loess sequence, Vojvodina, Serbia. Boreas 37, 66-73.

Galbraith, R. F., Roberts, R. G., Laslett, G. M., Yoshida, H. \& Olley, J. M. 1999: Optical Dating of Single and Multiple Grains of Quartz from Jinmium Rock Shelter, Northern Australia: Part I, Experimental Design and Statistical Models. Archaeometry 41, 339-364.

Guérin, G., Mercier, N. \& Adamiec, G. 2011: Dose-rate conversion factors: update. Ancient TL 29, 58 . 
1 Haase, D., Fink, J., Haase, G., Ruske, R., Pécsi, M., Richter, H., Altermann, M. \& Jäger, K.-D. 2007:

2

3

4

5

6

7

8

9

10 Loess in Europe its spatial distribution based on a European Loess Map, scale 1:2,500,000. Quaternary Science Reviews 26, 1301-1312.

Huntley, D. J. \& Baril, M. R. 1997: The K-content of the K-feldspars being measured in optical dating or in thermoluminescence dating. Ancient TL 15, 11-13.

Huntley, D. J., Godfrey-Smith, D. I. \& Haskell, E. H. 1991: Light-induced emission spectra from some quartz and feldspars. Nuclear Tracks and Radiation Measurements 18, 127-131.

Jordanova, D., Hus, J., Evlogiev, J. \& Geeraerts, R. 2008: Palaeomagnetism of the loess/paleosol sequence in Viatovo (NE Bulgaria) in the Danube basin. Physics of the Earth and Planetary Interiors 167, 71-83.

Jordanova, D., Hus, J. \& Geeraerts, R. 2007: Palaeoclimatic implications of the magnetic record from loess/paleosol sequence Viatovo (NE Bulgaria). Geophysical Journal International 171, 10361047.

Jordanova, D. \& Petersen, N. 1999: Palaeoclimatic record from a loess-soil profile in northeastern Bulgaria-I. Rock magnetic properties. Geophysical Journal International 138, 520-532.

Klasen, N., Loibl, C., Rethemeyer, J. \& Lehmkuhl, F. 2017: Testing feldspar and quartz luminescence dating of sandy loess sediments from the Doroshivtsy site (Ukraine) against radiocarbon dating. Quaternary International 432, 13-19.

Klasen, N., Fiebig, M. \& Preusser, F. 2016: Applying luminescence methodology to key sites of Alpine glaciations in Southern Germany. Quaternary International 420, 249-258.

Kreutzer, S., Fuchs, M., Meszner, S. \& Faust, D. 2012: OSL chronostratigraphy of a loess-paleosol sequence in Saxony/Germany using quartz of different grain sizes. Quaternary Geochronology $10,102-109$.

Kukla, G. J. 1975: Loess stratigraphy of Central Europe. In Butzer, K. W. \& Isaac, G. L. (eds.): After the Australopithecines, 99-188. Mouton Publishers, The Hague. 
1 Lai, Z.-P. 2010: Chronology and the upper dating limit for loess samples from Luochuan section in the

2

3

4

5

6

7

8 Chinese Loess Plateau using quartz OSL SAR protocol. Journal of Asian Earth Sciences 37, 176-185.

Lai, Z.-P. \& Fan, A. 2013: Examining quartz OSL age underestimation for loess samples from Luochuan in the Chinese Loess Plateau. Geochronometria 41, 57-64.

Li, B. \& Li, S.-H. 2011: Luminescence dating of K-feldspar from sediments: A protocol without anomalous fading correction. Quaternary Geochronology 6, 468-479.

Lomax, J., Mittelstraß, D., Kreutzer, S. \& Fuchs, M. 2015: OSL, TL and IRSL emission spectra of sedimentary quartz and feldspar samples. Radiation Measurements 81, 251-256.

Lomax, J., Kreutzer, S. \& Fuchs, M. 2014: Performance tests using the Lexsyg luminescence reader. Geochronometria 41, 327-333.

Lowick, S. E. \& Valla, P. G. 2018: Characterising the luminescence behaviour of 'infinitely old' quartz samples from Switzerland. Quaternary Geochronology 43, 1-11.

Lowick, S. E., Buechi, M. W., Gaar, D., Graf, H. R. \& Preusser, F. 2015: Luminescence dating of Middle Pleistocene proglacial deposits from northern Switzerland: methodological aspects and stratigraphical conclusions. Boreas 44, 459-482.

Lowick, S. E., Trauerstein, M. \& Preusser, F. 2012: Testing the application of post IR-IRSL dating to fine grain waterlain sediments. Quaternary Geochronology 8, 33-40.

Lowick, S. E. \& Preusser, F. 2011: Investigating age underestimation in the high dose region of optically stimulated luminescence using fine grain quartz. Quaternary Geochronology 6, 33-41.

Lowick, S. E., Preusser, F., Pini, R. \& Ravazzi, C. 2010: Underestimation of fine grain quartz OSL dating towards the Eemian: Comparison with palynostratigraphy from Azzano Decimo, northeastern Italy. Quaternary Geochronology 5, 583-590. 
1 Marković, S. B., Fitzsimmons, K. E., Sprafke, T., Gavrilović, D., Smalley, I. J., Jović, V., Svircev, Z.,

2

3

4

5

6

7

8

Gavrilov, M. B. \& Beslin, M. 2016: The history of Danube loess research. Quaternary International 399, 86-99.

Marković, S. B., Stevens, T., Kukla, G. J., Hambach, U., Fitzsimmons, K. E., Gibbard, P., Buggle, B., Zech, M., Guo, Z., Hao, Q., Wu, H., O'Hara Dhand, K., Smalley, I. J., Újvári, G., Sümegi, P., Timar-Gabor, A., Veres, D., Sirocko, F., Vasiljević, D. A., Jary, Z., Svensson, A., Jović, V., Lehmkuhl, F., Kovács, J. \& Svirčev, Z. 2015: Danube loess stratigraphy — Towards a panEuropean loess stratigraphic model. Earth-Science Reviews 148, 228-258.

Marković, S. B., Hambach, U., Catto, N., Jovanović, M., Buggle, B., Machalett, B., Zöller, L., Glaser, B. \& Frechen, M. 2009: Middle and Late Pleistocene loess sequences at Batajnica, Vojvodina, Serbia. Quaternary International 198, 255-266.

Moine, O., Antoine, P., Hatté, C., Landais, A., Mathieu, J., Prud'homme, C. \& Rousseau, D.-D. 2017: The impact of Last Glacial climate variability in west-European loess revealed by radiocarbon dating of fossil earthworm granules. Proceedings of the National Academy of Sciences of the USA 114, 6209-6214.

Murray, A., Schmidt, E., Stevens, T., Buylaert, J.-P., Marković, S., Tsukamoto, S. \& Frechen, M. 2014: Dating Middle Pleistocene loess from Stari Slankamen (Vojvodina, Serbia) Limitations imposed by the saturation behaviour of an elevated temperature IRSL signal. Catena 117, 34-42.

Murray, A. \& Wintle, A. 2000: Luminescence dating of quartz using an improved single-aliquot regenerative-dose protocol. Radiation Measurements 32, 57-73.

Murray, A. \& Wintle, A. 2003: The single aliquot regenerative dose protocol: potential for improvements in reliability. Radiation Measurements 37, 377-381.

Novothny, Á., Frechen, M., Horváth, E., Krbetschek, M. \& Tsukamoto, S. 2010: Infrared stimulated luminescence and radiofluorescence dating of aeolian sediments from Hungary. Quaternary Geochronology 5, 114-119. 
1 Novothny, Á., Frechen, M., Horváth, E., Wacha, L. \& Rolf, C. 2011: Investigating the penultimate and 2 last glacial cycles of the Süttő loess section (Hungary) using luminescence dating, highresolution grain size, and magnetic susceptibility data. Quaternary International 234, 75-85.

4 Obreht, I., Zeeden, C., Hambach, U., Veres, D., Marković, S. B., Bösken, J., Svirčev, Z., Bačević, N., Gavrilov, M. B. \& Lehmkuhl, F. 2016: Tracing the influence of Mediterranean climate on Southeastern Europe during the past 350,000 years. Scientific Reports 6, 36334; doi: $10.1038 /$ srep36334.

Panaiotu, C., Panaiotu, E., Grama, A. \& Necula, C. 2001: Paleoclimatic record from a loess-paleosol profile in southeastern Romania. Physics and Chemistry of the Earth, Part A: Solid Earth and Geodesy 26, 893-898.

Prescott, J. \& Hutton, J. 1988: Cosmic ray and gamma ray dosimetry for TL and ESR. International Journal of Radiation Applications and Instrumentation. Part D. Nuclear Tracks and Radiation Measurements 14, 223-227.

Prescott, J. \& Hutton, J. 1994: Cosmic ray contributions to dose rates for luminescence and ESR dating: Large depths and long-term time variations. Radiation Measurements 23, 497-500.

Rees-Jones, J. 1995: Optical dating of young sediments using fine-grain quartz. Ancient TL 13, 9-14.

Reimann, T., Thomsen, K. J., Jain, M., Murray, A. S. \& Frechen, M. 2012: Single-grain dating of young sediments using the pIRIR signal from feldspar. Quaternary Geochronology 11, 28-41.

Roberts, H. M. 2012: Testing Post-IR IRSL protocols for minimising fading in feldspars, using Alaskan loess with independent chronological control. Radiation Measurements 47, 716-724.

Stevens, T., Marković, S. B., Zech, M., Hambach, U. \& Sümegi, P. 2011: Dust deposition and climate in the Carpathian Basin over an independently dated last glacial-interglacial cycle. Quaternary Science Reviews 30, 662-681. 
1 Thiel, C., Buylaert, J.-P., Murray, A., Terhorst, B., Hofer, I., Tsukamoto, S. \& Frechen, M. 2011:

2

3

4

5

6 Luminescence dating of the Stratzing loess profile (Austria) - Testing the potential of an elevated temperature post-IR IRSL protocol. Quaternary International 234, 23-31.

Thomsen, K., Murray, A., Jain, M. \& Bøtter-Jensen, L. 2008: Laboratory fading rates of various luminescence signals from feldspar-rich sediment extracts. Radiation Measurements 43, 1474 1486.

Timar-Gabor, A., Buylaert, J.-P., Guralnik, B., Trandafir-Antohi, O., Constantin, D., Anechitei-Deacu, V., Jain, M., Murray, A. S., Porat, N., Hao, Q. \& Wintle, A.G. 2017: On the importance of grain size in luminescence dating using quartz. Radiation Measurements 106, 464-471.

Timar-Gabor, A., Constantin, D., Buylaert, J.P., Jain, M., Murray, A.S. \& Wintle, A.G. 2015a: Fundamental investigations of natural and laboratory generated SAR dose response curves for quartz OSL in the high dose range. Radiation Measurements 81, 150-156.

Timar-Gabor, A., Constantin, D., Marković, S. \& Jain, M. 2015b: Extending the area of investigation of fine versus coarse quartz optical ages from the Lower Danube to the Carpathian Basin. Quaternary International 388, 168-176.

Timar-Gabor, A.\& Wintle, A. 2013: On natural and laboratory generated dose response curves for quartz of different grain sizes from Romanian loess. Quaternary Geochronology 18, 34-40.

Timar-Gabor, A., Vasiliniuc, Ș., Vandenberghe, D., Cosma, C. \& Wintle, A. 2012: Investigations into the reliability of SAR-OSL equivalent doses obtained for quartz samples displaying dose response curves with more than one component. Radiation Measurements 47, 740-745.

Timar-Gabor, A., Vandenberghe, D., Vasiliniuc, S., Panaoitu, C., Panaiotu, C., Dimofte, D. \& Cosma, C. 2011: Optical dating of Romanian loess: A comparison between silt-sized and sand-sized quartz. Quaternary International 240, 62-70.

Timar, A., Vandenberghe, D., Panaiotu, E., Panaiotu, C., Necula, C., Cosma, C. \& van den Haute, P. 2010: Optical dating of Romanian loess using fine-grained quartz. Quaternary Geochronology $5,143-148$. 
1 Újvári, G., Molnár, M., Novothny, Á., Páll-Gergely, B., Kovács, J. \& Várhegyi, A. 2014: AMS ${ }^{14}$ C

2

3

4

5

6

7

8 and OSL/IRSL dating of the Dunaszekcső loess sequence (Hungary): chronology for 20 to $150 \mathrm{ka}$ and implications for establishing reliable age-depth models for the last $40 \mathrm{ka}$. Quaternary Science Reviews 106, 140-154.

Valet, J.P., Bassinot, F., Bouilloux, A., Bourlès, D., Nomade, S., Guillou, V., Lopes, F., Thouveny, N. \& Dewilde, F. 2014 : Geomagnetic, cosmogenic and climatic changes across the last geomagnetic reversal from Equatorial Indian Ocean sediments. Earth and Planetary Science Letters 397, 67-79.

Vandenberghe, J., Markovič, S., Jovanovič, M. \& Hambach, U. 2014: Site-specific variability of loess and paleosols (Ruma, Vojvodina, northern Serbia). Quaternary International 334-335, 86-93.

Vasiliniuc, Ş., Vandenberghe, D., Timar-Gabor, A., Panaiotu, C., Cosma, C. \& van den Haute, P. 2012: Testing the potential of elevated temperature post-IR IRSL signals for dating Romanian loess. Quaternary Geochronology 10, 75-80.

Veres, D., Lane, C. S., Timar-Gabor, A., Hambach, U., Constantin, D., Szakács, A., Fülling, A., Onaca, B. P., 2013: The Campanian Ignimbrite/Y5 tephra layer - A regional stratigraphic marker for Isotope Stage 3 deposits in the Lower Danube region, Romania. Quaternary International 293, 22-33.

Vivo, B. De, Rolandi, G., Gans, P. B., Calvert, A., Bohrson, W. A., Spera, F. J. \& Belkin, H. E. 2001: New constraints on the pyroclastic eruptive history of the Campanian volcanic Plain (Italy). Mineralogy and Petrology 73, 47-65. 


\section{Figure captions}

2 Fig. 1 Study area showing the location of the loess sequence Harletz and other important loess 3 sequences discussed in the text. Loess distribution in yellow, after Haase et al. (2007).

4 Fig. 2. Stratigraphy of the studied loess sequence in Harletz (Bulgaria), with pedosedimentary units 5 presented in Table 1 and magnetic susceptibility data measured in the field (bottom scale) and in the 6 laboratory (top scale). Unit differentiation is based on field observations and was refined by 7 sedimentological and magnetic property data. Location of the samples taken for luminescence dating 8 with their laboratory numbers and luminescence ages estimates in ka are indicated. Unreliable ages are 9 given in grey. Q FG = Quartz fine grain; FS CG = Feldspar coarse grain.

10 Fig. 3. Growth curves of four $4 \mathrm{~mm}$-aliquots of the quartz coarse grain fraction. Natural doses were 11 measured using a conventional SAR protocol with four regeneration doses, and an exponential or 12 exponential + linear fitting.

13 Fig. 4. A. Growth curves of the quartz fine grain sample GI14 using an exponential + linear fitting. B. 14 Natural luminescence signal, luminescence signal of the first test dose, and response to IR stimulation 15 of the same sample.

16 Fig. 5. Extended Dose Recovery Tests of the fine grain quartz fraction of sample GI14. Laboratory 17 doses of 244, 305, 366, 427, 488 and 549 Gy were applied (red bars) and recovered with the same 18 SAR protocol used for the standard measurements (black dots). Also indicated is the respective dose 19 recovery ratio and the approximate maximum dose of the naturally irradiated samples.

Fig. 6. Equivalent doses $\left(D_{e}\right)$ versus stimulation temperature of the MET-pIRIR protocol of all 21 measured feldspar coarse grain samples. Also shown is the feldspar dose, which would be expected 22 from the quartz fine grain measurements, after transferring the quartz dose rate to the feldspar dose 23 rate. Resulting feldspar ages presented in Table 3 and Fig. 2 are based on a stimulation temperature of $24 \quad 150{ }^{\circ} \mathrm{C}$. 
1 Fig. 7. Main loess sequences in southeastern Europe (Carpathian Basin and Danube Plain) discussed in 2 the text, with their luminescence based chronologies. Dunaszeckcső (Újvári et al. 2014), Crvenka 3 (Stevens et al. 2011), Surduk (Fuchs et al. 2008), Mostistea and Mircea Voda (Balescu et al. 2010) 4 (see locations in Fig. 1). Luminescence ages of Timar et al. (2010), Timar-Gabor et al. (2011) and 5 Vasiliniuc et al. (2012) for the Mostistea and Mircea Voda section are not considered in the figure, but 6 are discussed in the text. For Harletz (this study), ages based on the MET-pIRIR protocol with a 7 stimulation temperature of $150{ }^{\circ} \mathrm{C}$ are shown.

8

\section{$9 \quad$ Table captions}

10 Table 1. Simplified description and pedosedimentary interpretation of the various pedosedimentary 11 units (soil labelling according to FAO UNESCO soil classification).

12 Table 2. Residual doses of feldspar coarse grain samples GI07 and GI11after three hours bleaching on 13 the window sill in full sunlight. Also given is the corresponding age, resulting from division with an 14 average dose rate of $3.4 \mathrm{~Gy} \mathrm{ka}^{-1}$.

15 Table 3. Radionuclide concentrations, dose rates, $D_{e}$ values and resulting luminescence ages of the 16 quartz fine grain and feldspar coarse grain fraction.

17

\section{Supporting Information}

19 marks the administered dose (134 Gy).

22 Fig. S2. Results of a fading test on the feldspar coarse grain fraction of sample GI09, following Auclair et al. (2003), adapted to the MET-pIRIR protocol. 


\begin{tabular}{ccccc}
\hline $\begin{array}{c}\text { Stimulation } \\
\text { temperature }\left({ }^{\circ} \mathrm{C}\right)\end{array}$ & $\begin{array}{c}\text { GI07 residual } \\
\text { dose }(\mathrm{Gy})\end{array}$ & $\begin{array}{c}\text { Approximate age } \\
\text { equivalent }(\mathrm{ka})\end{array}$ & $\begin{array}{c}\text { GI11 residual } \\
\text { dose }(\mathrm{Gy})\end{array}$ & $\begin{array}{c}\text { Approximate age } \\
\text { equivalent }(\mathrm{ka})\end{array}$ \\
\hline 50 & $1.5 \pm 0.0$ & 0.5 & $1.6 \pm 0.3$ & 0.5 \\
100 & $9.7 \pm 1.0$ & 2.9 & $9.2 \pm 0.6$ & 2.7 \\
150 & $13.9 \pm 0.9$ & 4.1 & $13.6 \pm 1.0$ & 4.0 \\
200 & $18.2 \pm 2.7$ & 5.3 & $18.1 \pm 0.8$ & 5.3 \\
250 & $24.9 \pm 0.8$ & 7.3 & $23.5 \pm 1.5$ & 6.9 \\
\hline
\end{tabular}




\begin{tabular}{|c|c|c|c|c|c|c|c|c|c|c|c|c|c|}
\hline \multirow[t]{2}{*}{ Sample } & \multirow{2}{*}{$\begin{array}{l}\text { Depth } \\
(\mathrm{m})\end{array}$} & \multirow[t]{2}{*}{ Unit } & \multirow{2}{*}{$\begin{array}{c}\text { Water } \\
(\%)\end{array}$} & \multirow{2}{*}{$\begin{array}{c}n \\
(\mathrm{Q} / \mathrm{FS})\end{array}$} & \multicolumn{2}{|c|}{$\mathrm{D}_{\mathrm{e}}$ (Gy) } & \multirow{2}{*}{$\begin{array}{c}U \\
\text { (ppm) }\end{array}$} & \multirow{2}{*}{$\begin{array}{c}\text { Th } \\
(\mathrm{ppm})\end{array}$} & \multirow{2}{*}{$\begin{array}{c}K \\
(\%)\end{array}$} & \multicolumn{2}{|c|}{ Dose rate $\left(G_{y ~ k a}{ }^{-1}\right)$} & \multicolumn{2}{|c|}{ Age (ka) } \\
\hline & & & & & $Q$ & FS & & & & $Q$ & FS & $Q$ & FS \\
\hline Gi05 & 1.35 & $1 b$ & 12 & $6 / 5$ & $142 \pm 5$ & $141 \pm 7$ & $3.85 \pm 0.32$ & $9.52 \pm 1.05$ & $1.52 \pm 0.08$ & $3.56 \pm 0.21$ & $3.65 \pm 0.23$ & $40 \pm 3$ & $39 \pm 3$ \\
\hline Gi06 & 2.80 & $1 c$ & - & $-/-$ & - & - & $3.76 \pm 0.32$ & $8.59 \pm 1.00$ & $1.47 \pm 0.07$ & - & - & - & - \\
\hline Gi07 & 4.00 & $1 d$ & 12 & $6 / 8$ & $197 \pm 6$ & $217 \pm 9$ & $4.12 \pm 0.29$ & $7.59 \pm 0.96$ & $1.53 \pm 0.08$ & $3.43 \pm 0.21$ & $3.53 \pm 0.23$ & $57 \pm 4$ & $62 \pm 5$ \\
\hline Gi08 & 4.45 & $2 a$ & 15 & $6 /-$ & $227 \pm 7$ & - & $3.34 \pm 0.30$ & $7.48 \pm 0.93$ & $1.50 \pm 0.08$ & $3.06 \pm 0.18$ & - & $74 \pm 5$ & - \\
\hline Gi09 & 5.20 & $2 b$ & 15 & $6 / 6$ & $267 \pm 9$ & $252 \pm 14$ & $3.26 \pm 0.26$ & $7.53 \pm 0.85$ & $1.39 \pm 0.07$ & $2.93 \pm 0.17$ & $3.07 \pm 0.20$ & $91 \pm 6$ & $82 \pm 7$ \\
\hline Gi10 & 7.60 & $3 b$ & 12 & $6 / 5$ & $297 \pm 10$ & $485 \pm 30$ & $3.46 \pm 0.28$ & $9.07 \pm 0.94$ & $1.50 \pm 0.07$ & $3.29 \pm 0.20$ & $3.40 \pm 0.22$ & $90 \pm 6$ & $142 \pm 13$ \\
\hline Gi11 & 8.70 & $3 b$ & 12 & $6 / 4$ & $320 \pm 10$ & $480 \pm 22$ & $3.58 \pm 0.28$ & $8.48 \pm 0.91$ & $1.50 \pm 0.08$ & $3.27 \pm 0.20$ & $3.38 \pm 0.22$ & $98 \pm 7$ & $142 \pm 11$ \\
\hline Gi12 & 9.90 & $3 b$ & 12 & $4 / 5$ & $339 \pm 13$ & $502 \pm 17$ & $3.04 \pm 0.31$ & $10.90 \pm 1.01$ & $1.49 \pm 0.07$ & $3.30 \pm 0.20$ & $3.41 \pm 0.23$ & $103 \pm 7$ & $147 \pm 11$ \\
\hline Gi13 & 11.45 & $3 b$ & 12 & $-/ 5$ & - & $579 \pm 28$ & $3.69 \pm 0.30$ & $8.52 \pm 0.98$ & $1.50 \pm 0.07$ & - & $3.39 \pm 0.23$ & - & $171 \pm 14$ \\
\hline Gi14 & 12.80 & 5 & 12 & $6 /-$ & $324 \pm 13$ & - & $3.94 \pm 0.30$ & $8.53 \pm 1.00$ & $1.60 \pm 0.08$ & $3.45 \pm 0.21$ & - & $94 \pm 7$ & - \\
\hline Gi15 & 14.05 & 8 & 12 & $6 /-$ & $339 \pm 14$ & - & $4.01 \pm 0.31$ & $8.95 \pm 1.03$ & $1.64 \pm 0.08$ & $3.54 \pm 0.22$ & - & $96 \pm 7$ & - \\
\hline Gi16 & 14.10 & 9 & 15 & $-/-$ & - & - & $4.32 \pm 0.30$ & $7.64 \pm 0.97$ & $1.64 \pm 0.08$ & - & - & - & - \\
\hline Gi17 & 15.55 & 11 & 15 & $6 / 5$ & $331 \pm 11$ & $429 \pm 16$ & $3.30 \pm 0.33$ & $10.62 \pm 1.08$ & $1.42 \pm 0.07$ & $3.16 \pm 0.19$ & $3.28 \pm 0.22$ & $105 \pm 7$ & $131 \pm 10$ \\
\hline Gi18 & 17.55 & $13 a$ & 20 & $6 /-$ & $345 \pm 13$ & - & $4.34 \pm 0.29$ & $7.15 \pm 0.94$ & $1.40 \pm 0.07$ & $2.99 \pm 0.18$ & & $115 \pm 8$ & - \\
\hline Gi19 & 18.40 & $13 b$ & 20 & $6 /-$ & $355 \pm 12$ & - & $3.80 \pm 0.27$ & $8.29 \pm 0.90$ & $1.47 \pm 0.07$ & $2.99 \pm 0.18$ & & $119 \pm 8$ & - \\
\hline Gi20 & 19.75 & 14 & 25 & $5 / 5$ & $332 \pm 12$ & $469 \pm 19$ & $3.66 \pm 0.26$ & $7.61 \pm 0.86$ & $1.77 \pm 0.09$ & $2.99 \pm 0.17$ & $3.14 \pm 0.20$ & $111 \pm 7$ & $149 \pm 11$ \\
\hline
\end{tabular}




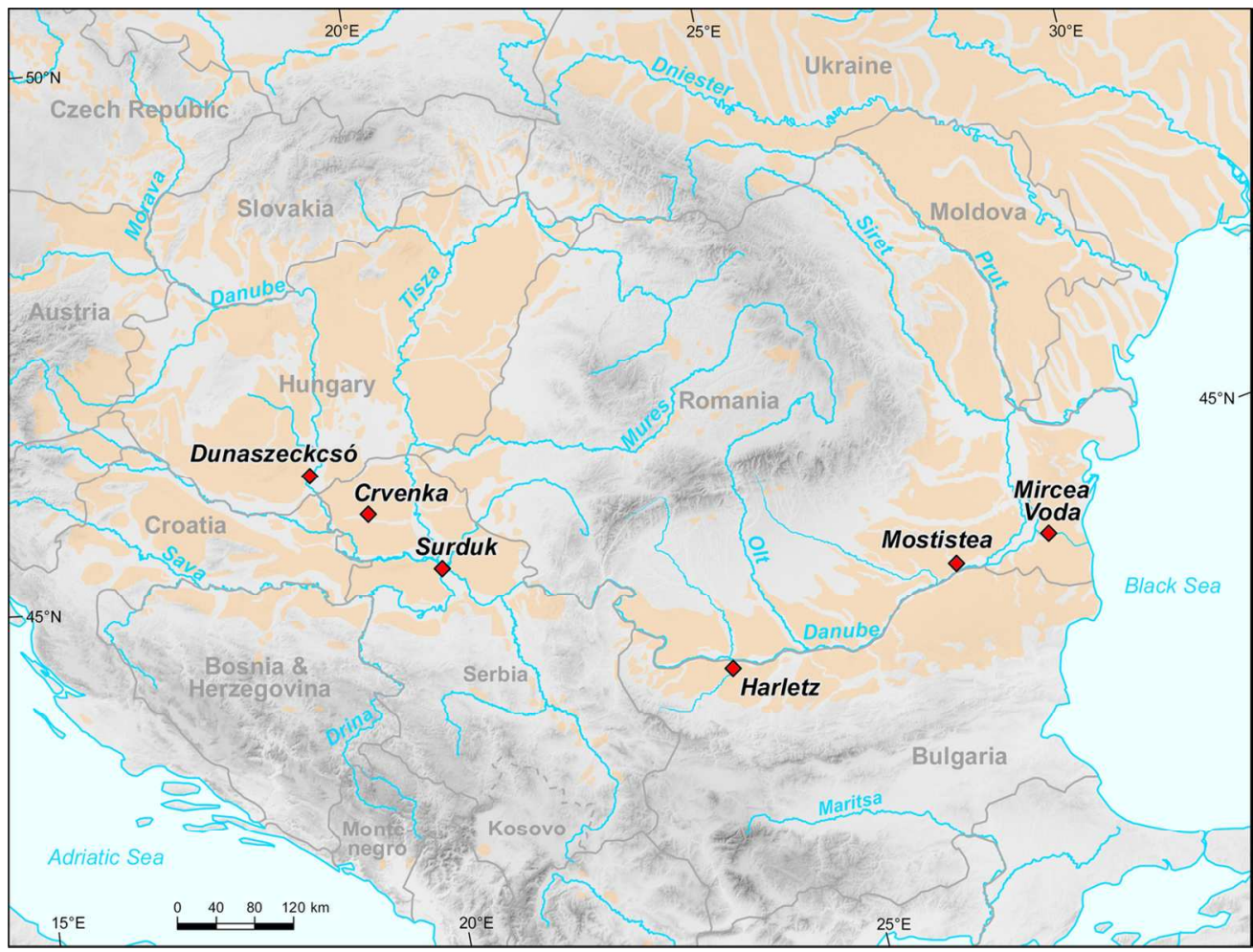

$122 \times 92 \mathrm{~mm}(300 \times 300$ DPI $)$ 


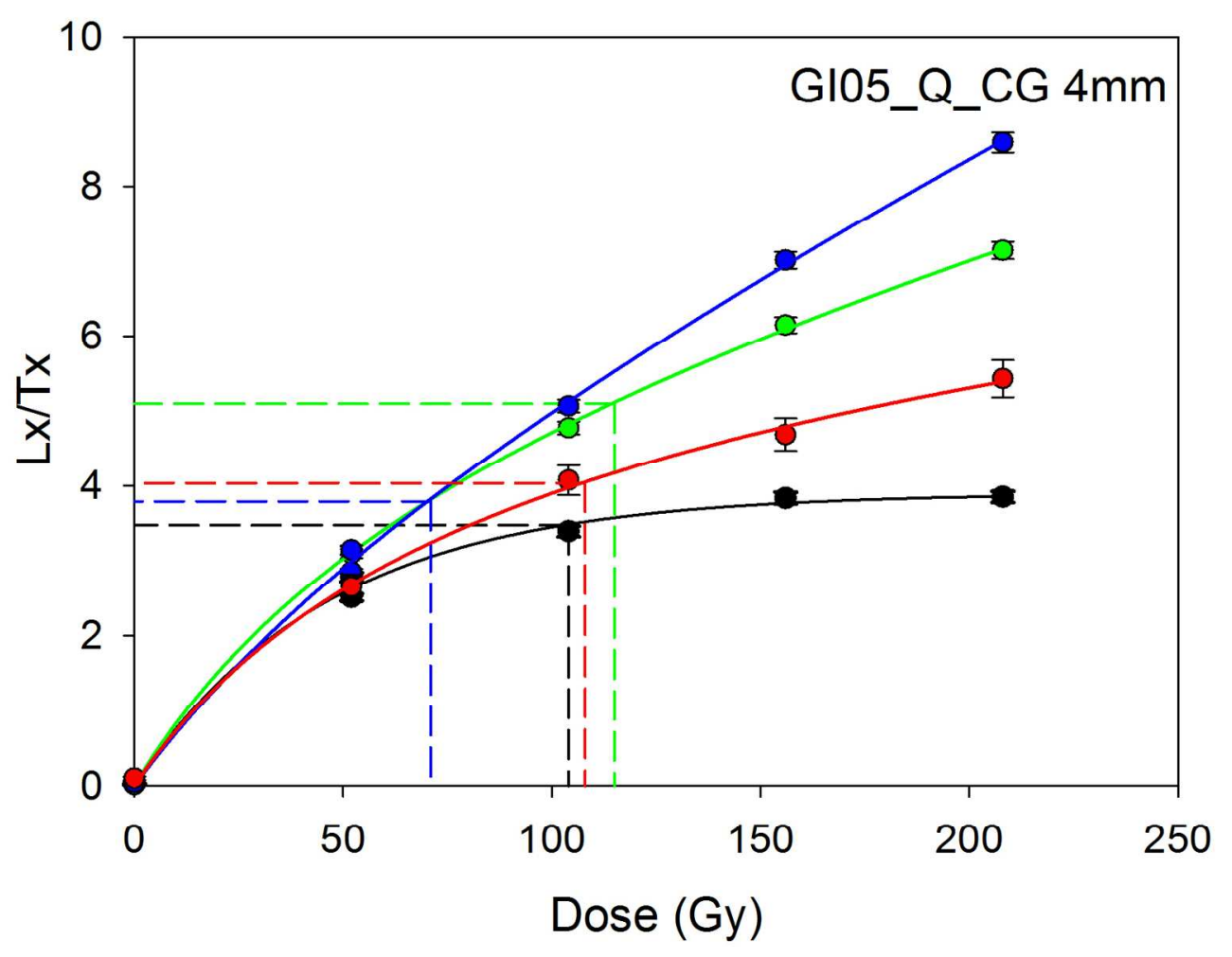

$147 \times 115 \mathrm{~mm}(300 \times 300 \mathrm{DPI})$ 

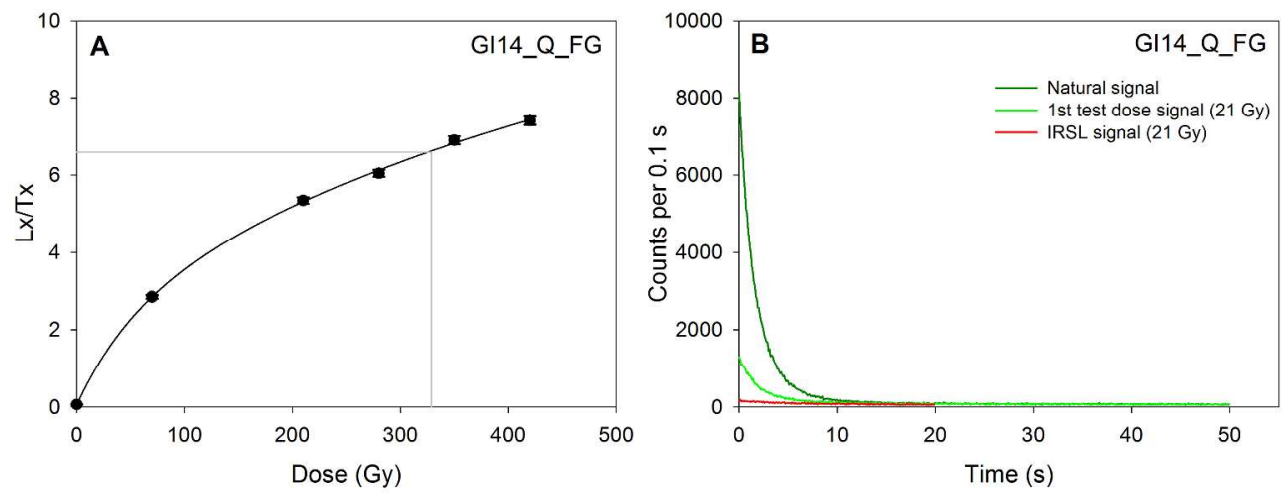

$301 \times 116 \mathrm{~mm}$ (300 x 300 DPI) 


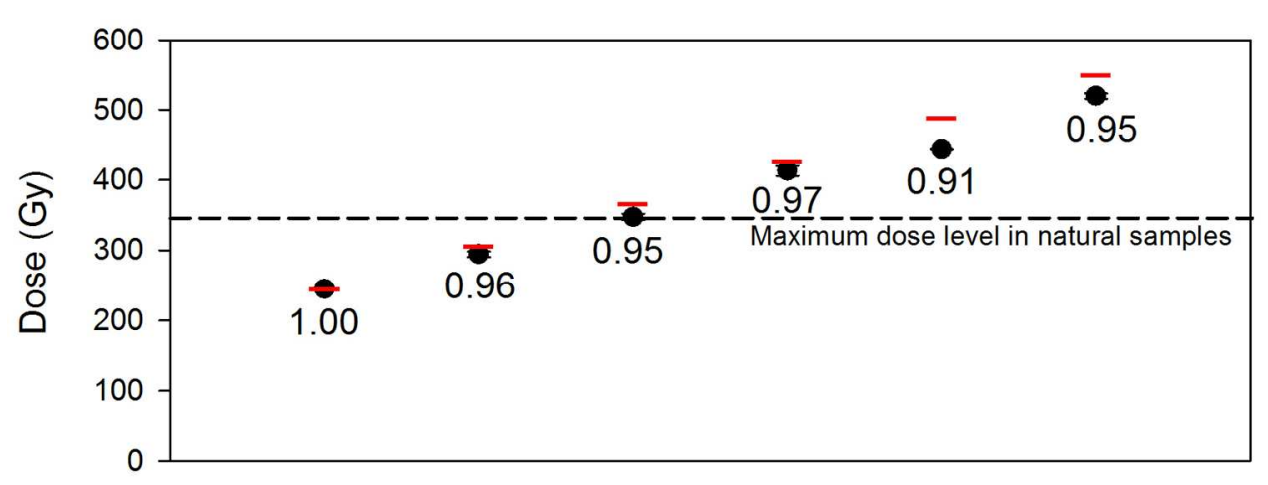

$150 \times 69 \mathrm{~mm}(300 \times 300 \mathrm{DPI})$ 


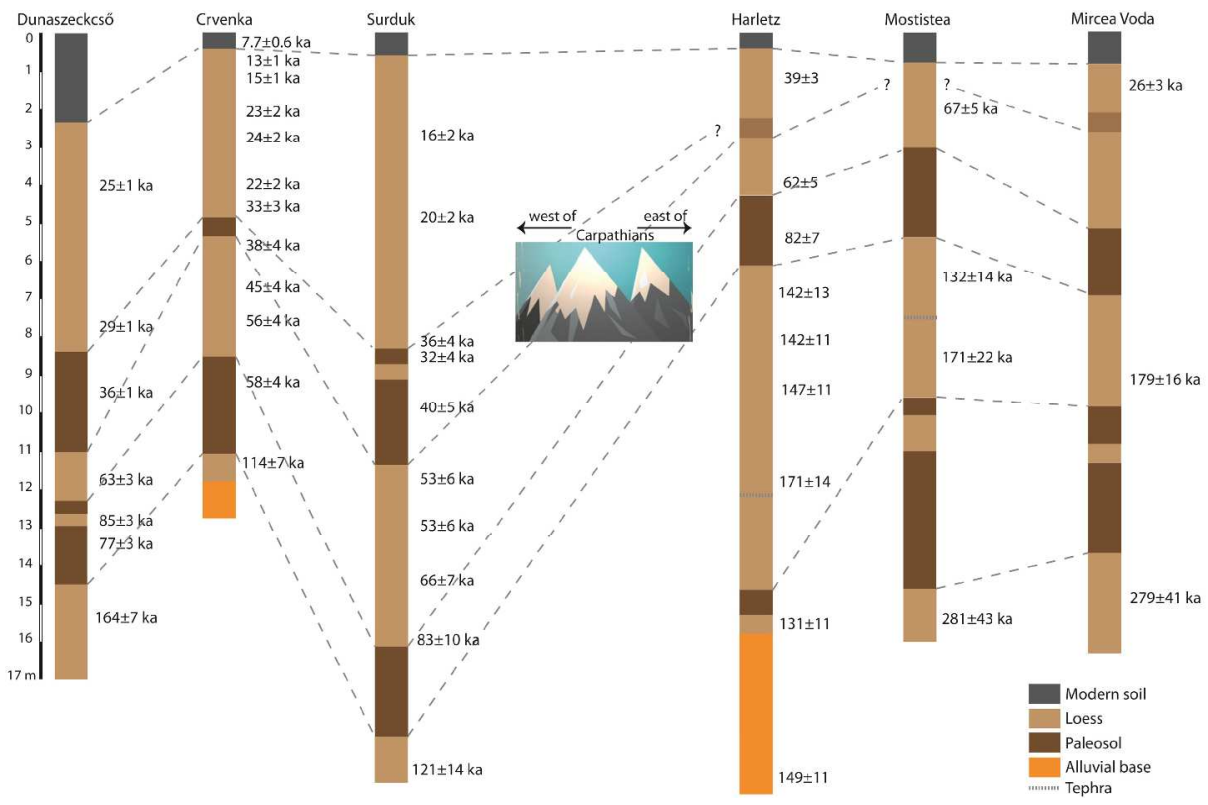

$286 \times 172 \mathrm{~mm}(300 \times 300$ DPI $)$ 

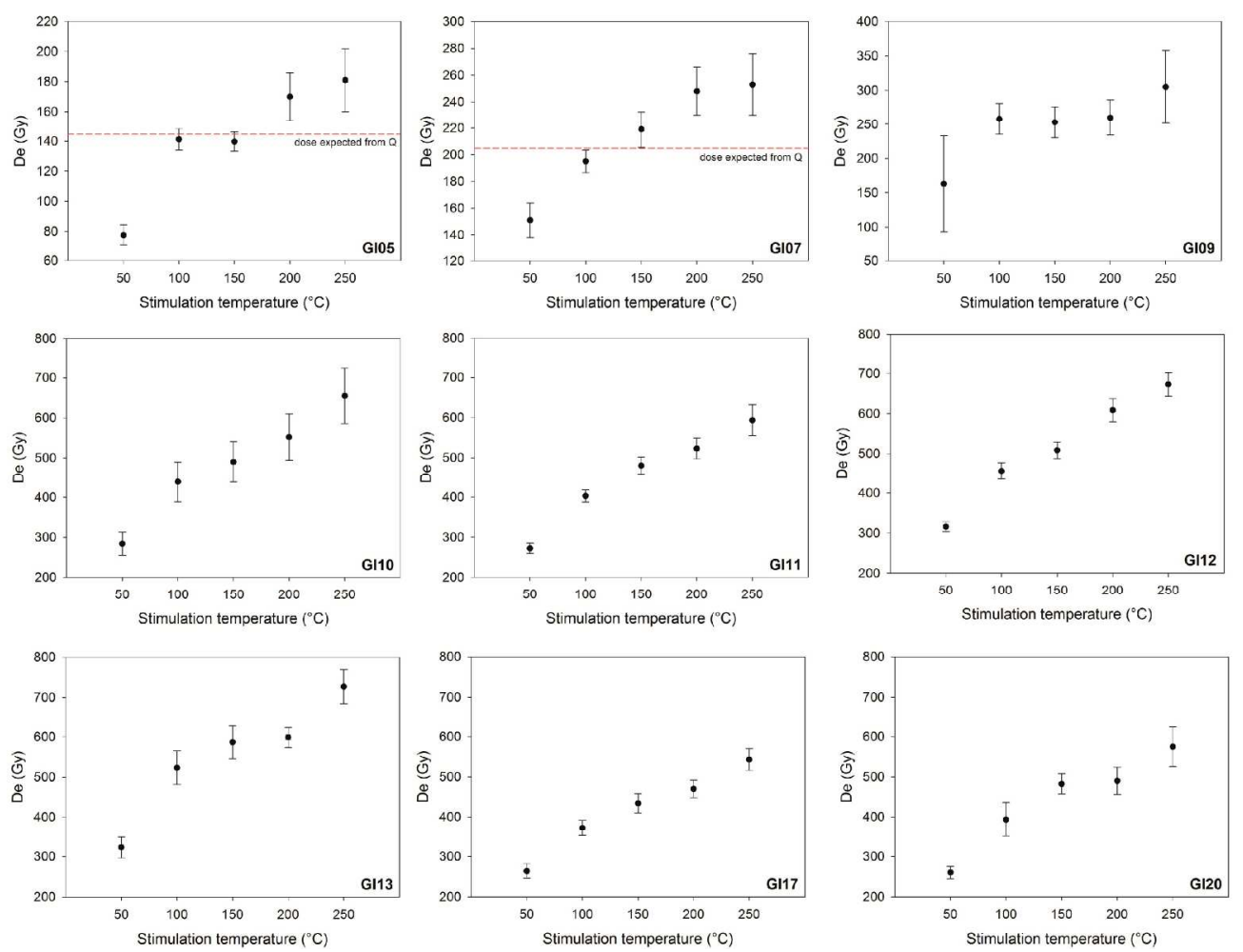

$194 \times 148 \mathrm{~mm}(300 \times 300$ DPI $)$ 

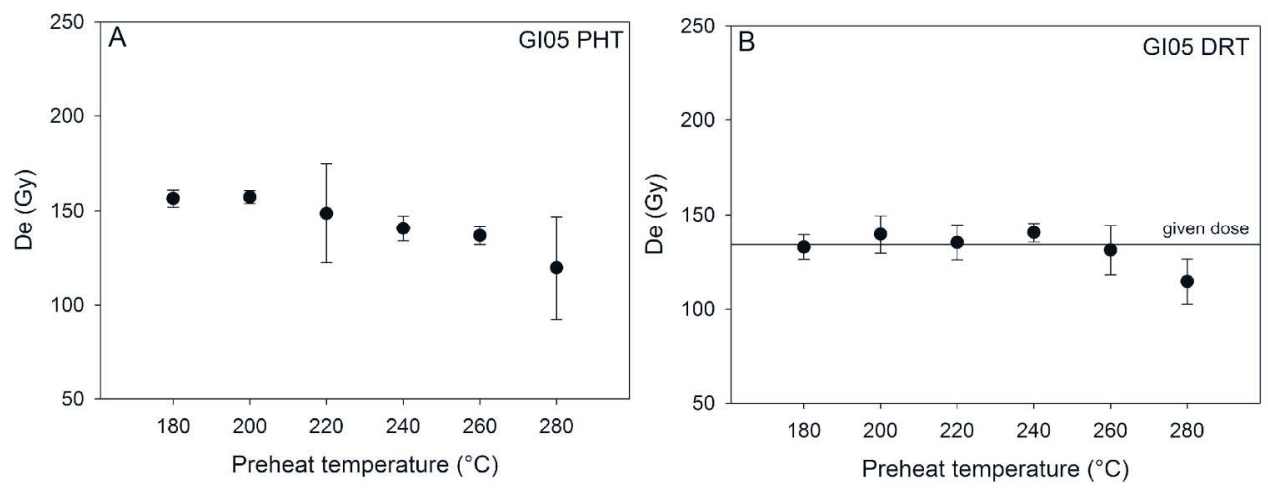

$806 \times 322 \mathrm{~mm}(72 \times 72$ DPI $)$ 

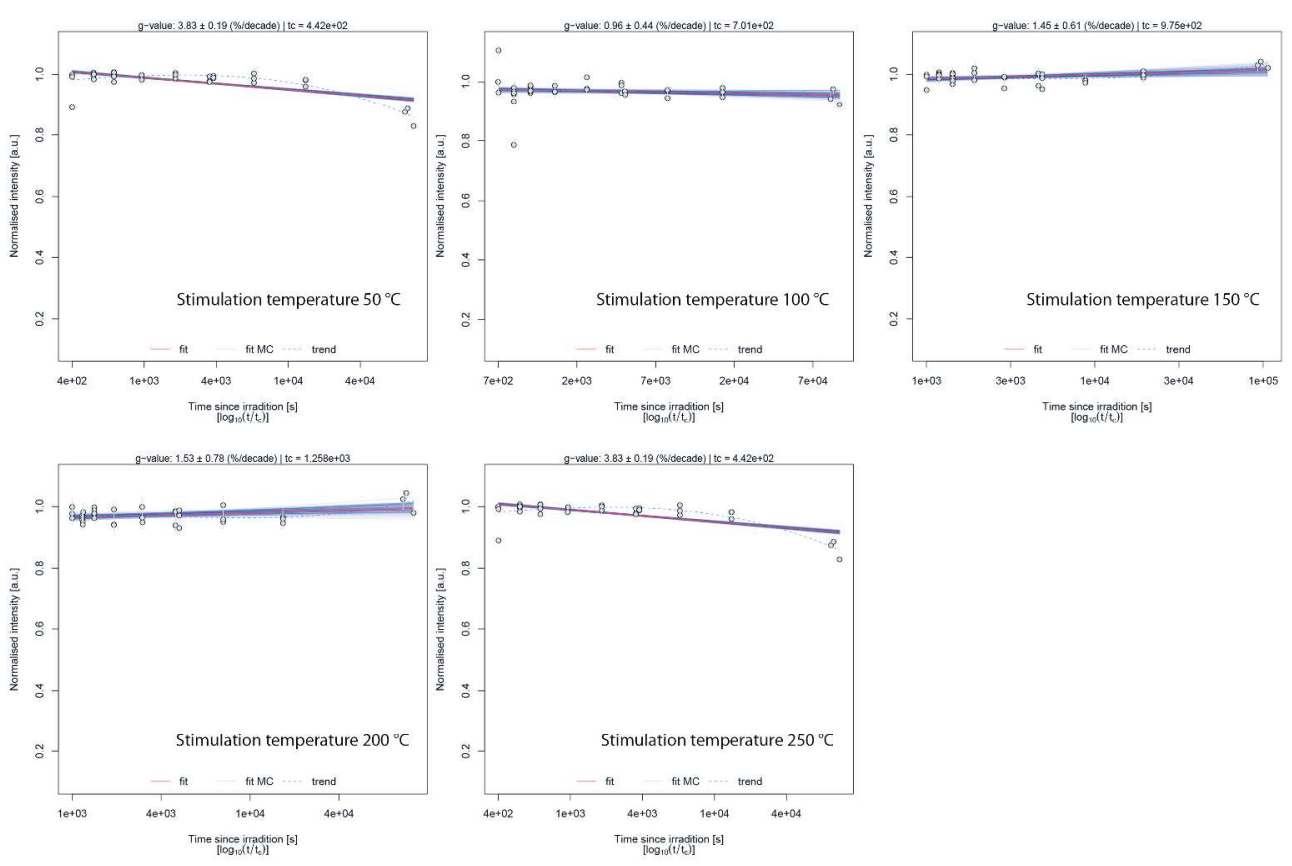

$258 \times 174 m m(300 \times 300$ DPI $)$ 